\title{
Development of High-level Talents Lecturer Team in Provincial Universities: Study on Tongren University, Guizhou, China
}

\author{
Yang Zhong Fei ${ }^{1 *}$ Foong Chee Haur ${ }^{2} \quad$ S.M. Ferdous Azam ${ }^{3}$ \\ Management and Science University, Seksyen 13, 40100, Shah Alam, Selangor, Malaysia
}

\begin{abstract}
The critical period of China's advanced education change, nearby common commonplace schools and colleges have changed from connected gifts to connected abilities, and schools have progressed to applied technology universities. The study at hand has been developed following a quantitative research method and tries to attain further understanding. Henceforth, the required primary data were collected by following a survey strategy by giving out self-administered questionnaires. Full-time teachers engaged in teaching at Tongren University in Guizhou, China were selected as the sampling frame for this study. The study showed that the Policy (POL) has a positive impact on Improving the Sustainable Development of Lecturers (SPD). The results of the study are given to the status quo of the construction of the lecturer team, the optimisation of the policy, and the average score of the sustainable development of the lecturer team with different professional qualifications and different levels of education. Colleges and universities must achieve self-use within the total number of approved preparations, position self-determination, high-level professional titles account for a higher proportion of job placement, selfdetermination of employment conditions, and independent employment of high-level talents. This study is limited to Tongren University and may not provide similar findings in a different university. However, this study can be used as a guideline for future study on other factors which will influence the development of high-level talent lecturer team.
\end{abstract}

Keywords: High-level Talents Lecturer Team, Tongren University Guizhou, China

DOI: $10.7176 / \mathrm{EJBM} / 11-14-02$

Publication date:May $31^{\text {st }} 2019$

\section{Introduction}

The new provincial-level colleges and universities are produced under the historical background of China's higher education reform. They have a vital historical mission in realising the popularisation of higher education and meeting people's different needs for higher education. Focusing on Tongren University, which is located in Tongren City, Guizhou Province, and is a famous city in western China. Tongren University previously established as an educational institution back in 1920. Since then only a few years back in 2006, it was approved by the Ministry of Education to establish a full-time provincial university. In 2010, it became a bachelor's degree-granting unit. Eventually, in 2013, it passed the assessment of the undergraduate teaching work of the Ministry of Education. After that in 2015, this university became the first application type in Guizhou Province. Besides that, there were many recent developments for that university as well.

The key to building a high-level applied university is to have a high-level teaching team, and the construction and management of high-level professional qualifications, high-educational degrees, and "double-teacher" lecturers are more important and difficult. Taking Tongren University as an example, this paper analyses the current situation of high-level talents in universities and the problems of high-level talents. In response to these problems, it puts forward some countermeasures to promote the development of high-level talent lecturers to promote Tongren College's early establishment of "double-class" teaching services.

Besides, in 2014, there were 53 senior professional qualifications, accounting for $8.9 \%$ of full-time teachers. In 2015 , there were 65 senior professional qualifications, accounting for $10.33 \%$ of the total number of full-time teachers. In 2016, there were 65 senior professional qualifications, accounting for the total number of full-time teachers. $9.23 \%$; in 2017, there were 82 senior professional qualifications, accounting for $11.32 \%$ of the total number of full-time teachers; in 2018, there were 89 senior professional qualifications, accounting for $12.37 \%$ of the total number of full-time teachers (Tongren University, 2018). In 2014, the proportion of doctors accounted for $4.75 \%$ of full-time teachers; in 2015 , the proportion of doctors accounted for $5.08 \%$ of full-time teachers; in 2016 , the proportion of doctors accounted for $7.78 \%$ of full-time teachers; in 2018, the proportion of doctors accounted for $14.74 \%$ of full-time teachers (Tongren University, 2018).

As of December 2018, there were 89 senior professional qualifications, accounting for $12.37 \%$ of the total number of full-time teachers (Tongren University, 2018). Because the professional qualification structure of teachers is not reason enough, the quality of teachers directly affects the quality of teaching, which directly affects the overall quality of teachers, and also affects the development of the overall teaching staff of the university. Besides, the number of doctors was 106, accounting for $14.74 \%$ of full-time teachers (Tongren University, 2018). From the perspective of long-term development of disciplines, it is necessary to speed up the pace of increasing the proportion of academic degree talents and further improve the level of discipline construction in universities. 
Besides, another concern is the construction of the "double- teacher" lecturer team is relatively lagging. In 2018, the number of "double- teacher" teachers was 320 (Tongren University, 2018), but the lack of high-level professional and technical personnel with practical experience, most of the professional and technical level is not high, only obtained professional technical certificates, did not penetrate the industry, It also lacks the practical experience of enterprises. It can only be used for academic teaching and cannot guide students' practice. Students lack professional guidance in practice and training, which is not conducive to the cultivation of applied talents.

This paper mainly studies how to improve the professional qualification structure of lecturers, how to optimise the education level of the lecturer team, and how to establish and improve the "double teacher system" lecturer evaluation system. Moreover, this research will help to promote the development of high-level talent lecturers in other provincial universities in Guizhou Province and help other provinces in China.

\section{Literature Review}

The first half of this review provides a theoretical basis for this study and the other half reviews recent literature. The recent literature mainly focuses on the professional qualification structure, academic degree structure, "double-skilled" teachers, policies, and the development of high-level talent lecturers. Moreover, this literature review section starts with the theoretical review for the research phenomenon.

\subsection{Two-Factor Theory (Fredrick Herzberg, 1959)}

This theory points out that the factors that can bring positive, satisfactory, and stimulating effects to work are called "incentives". Those who bring negative work, work conditions and atmosphere are all "health factors", such as policy management, salary treatment, wages and benefits, work environment, interpersonal relationship and so on. When employees have no objection to these factors, they only play a role in eliminating satisfaction, but they do not play a role in stimulating employees' enthusiasm. These factors are equivalent to the most basic physiological needs and safety needs of Maslow's hierarchy theory. Feeling needs to wait for lower level needs. Improving the "health factor" can only reduce the employee's dissatisfaction, but it cannot be an incentive. It only reduces dissatisfaction. To stimulate the individual initiative of employees, we must pay attention to the "incentive factors." For any organisation, the enthusiasm of the members of the organisation is the core driving force and critical factor for the realisation of the organisation's goals. For the newly-built local, provincial colleges and universities, building a "double- teacher" lecturer team need to be highly aware of the "incentives". The important role of "factors" attracts more "double- teacher" teachers, injecting new power and strength into the development of university lecturers, and providing lecturer protection for the transformation of universities into applied technology universities.

\subsection{Expectation Theory (Victor H. Vroom, 1964)}

This theory reflects the relationship between needs and goals by three factors: titer, means, expectation, and three factors. The theory proposes the key to motivating employees, that is, employee awareness. The importance of getting to work and only work can give them what they want; what they want is linked to performance; as long as they work hard, they can improve their performance.

\subsection{Attribution Theory (Fritz Heider, 1958)}

Attribution theory is primarily a theory that can guide people to find internal and external causes in everyday life. The role of attribution in the process of teacher motivation is particularly important. When teachers encounter setbacks in the teaching process, managers should actively guide them to help them objectively analyse and identify failure attributions in time, re-establish and maintain Self-confidence, while taking effective measures to prepare teachers for their success again adequately.

\subsection{Frustration Theory (Adams, 1939)}

Frustration theory mainly refers to the emotional state of a human individual when it is engaged in purposeful activity, the behaviour of pointing to the target is impeded or interfered, so that its motive cannot be realised, and the need to be satisfied. The theory of frustration mainly reveals that the human's motivational behaviour is hindered and fails to meet the psychological state when needed, and the behavioural performance caused by it and strives to take measures to transform harmful sexual behaviour into positive and constructive behaviour. Frustration has duality. It is both a bad thing and a good thing. It can make people suffer and disappoint. It can also make people wake up in mistakes, recognise mistakes, correct mistakes, become smart and mature.

\subsection{Empirical Review}

From the four aspects of reforming the university development model, perfecting the talent introduction mechanism, personnel training mechanism and management mechanism, the paper proposes the construction path of the local college lecturer team under the background of "double first-class"; Zhang Xiaoxu (2014) believes that 
the local, new provincial-level Colleges and universities have a big gap with the old provincial universities in terms of geographical location, university level, teaching level, welfare treatment, scientific research environment, etc. Therefore, the introduction of senior professional qualified talents faces many difficulties, so the university should recognise its characteristics. Moreover, lack, seize opportunities and challenges and aim to improve the core competitiveness of universities. Yang Yuhua (2011) proposed that "the academic leader has a long training period and it is difficult to introduce. Because compared with the old universities, the newly established local undergraduate colleges are in a competitive disadvantage in terms of geography, fame, academic environment and treatment. It is confusing for International students to introduce senior professional qualifications.

The loss of high-level professional qualifications and high-educational degree talents is severe. Chen Yongmei (2018) believes that the traditional old-fashioned colleges and universities use the university's geographical and famous reputation, the superiority of the academic environment, and the excellent treatment of recruiting talents everywhere, recruiting talents, always adding lecturers and storing lecturers. The resulting "black hole inhalation effect" makes new construction. Excellent lecturers at local, provincial universities are continually losing. Zhu Boyong, Luo Xuesong (2018), Huang Jianxiong, and Zhang Jiping (2013) believe that there are some problems in the structure of the lecturers in colleges and universities in China, mainly because of the shortage of highly educated teachers, and the need to reform teachers' qualifications, employment standards, and professional Qualification promotion procedures, training methods and other systems to optimize the structure of the lecturer team. Fan Lin (2010) believes that because most of the newly-built provincial-level universities are located in small and medium-sized cities, where the local economic development level is insufficient, investment is insufficient, and university conditions are relatively weak, so the lack of attractiveness for senior professional qualifications, and the university is cultivating After some teachers obtained advanced professional qualifications, the loss of senior professional qualifications was caused by the welfare of the university and other reasons. It is believed that newly-built local provincial-level colleges and universities are in a less developed place, and they urgently need masters and doctors with professional advantages to join. It is difficult for colleges and universities to recruit high-educational degree talents who meet the actual needs, even if they recruit highly educated top talents. It is still tricky for high-educated top-notch talents to stay in newly-built local provincial-level universities for teaching, resulting in teachers who are still undergraduate degrees accounting for the majority of the teaching staff.

The professional training system for senior professional qualifications and high academic degrees is not perfect. (Yao $\mathrm{Xu}, 2016$ ) That is the context of transformation and development, the overall professional qualification level of teachers is low, and the construction of local, new provincial-level college lecturers needs to develop a long-term plan for the construction of lecturers and broaden the channels for the introduction of highprofessional qualifications to adapt to transformational development. The need for full-time teachers, establish and improve the training mechanism for advanced professional qualifications, and establish a practical evaluation system; Liu Jun (2014) takes Hetao College as an example to study the construction of lecturers in local new provincial universities, and proposes the basis for running universities and development, rational planning and training of senior professional qualified talents, people-oriented, respecting teachers, enhancing the centripetal force and fostering of the teachers, increasing training, broadening the training channels, deepening the reform of the personnel distribution system, establishing an effective performance management mechanism for the teaching staff, and relying on The government's public resources ensure the development and construction of the teaching staff; Gao Jiaqi (2013) starts from the three central bodies of the government, universities and teachers, and looks for a valid path to improve the construction level of college lecturers. It points out that the government should lead the training of talents with the scientific concept of development. With the direction of the construction of the lecturer, the university should give full play to the construction of the lecturer. The role of the body, teachers, should start from their own, improve the quality of teaching and research, and cooperate with the promotion of the construction of lecturers; Yang Yuhua (2011) believes that the academic leaders have a long training period and high funding, compared with the old universities, new local undergraduate colleges In the geographical, fame, academic environment, treatment and other aspects of the competitive disadvantage, some young and middle-aged teachers with a promising future, after obtaining a doctorate or a professor, are easy to go out to old traditional universities.

Wang Yiding and Wang Weiying (2015) believe that the professional skill level of the "double- teacher" teacher team is not high; Guo Ying (2014) believes that the "double- teacher" teacher has a higher level of theoretical research but a lower level of research and development, and there are a heavy theory and light practice. The problem is that the number of teachers with industry background or engineering background is insufficient, and the proportion of part-time teachers with the rich practical experience from enterprises or industries is tiny. There are some problems in the number, composition and level of the "double- teacher" teacher team. It is challenging to meet the needs of the transformation and development of local undergraduate colleges, and it is urgent to improve.

Based on research, five indicators of professional qualification structure, academic degree structure, "doubleteacher" teachers, policies and lecturer teams are selected for quantitative investigation. Among them, the 
professional qualification structure, academic degree structure, and "double-skilled" teachers are the core indicators reflecting the current status of high-level lecturer team construction. Thus, the review of theoretical frameworks and empirical work in the previous section helps the identification of critical variables necessary for the current study. The following section will provide a clear explanation of each relationship between and among variables along with a definition suitable for the current study based on the findings of the literature. Moreover, Figure 1 presents the conceptual framework proposed for this study.

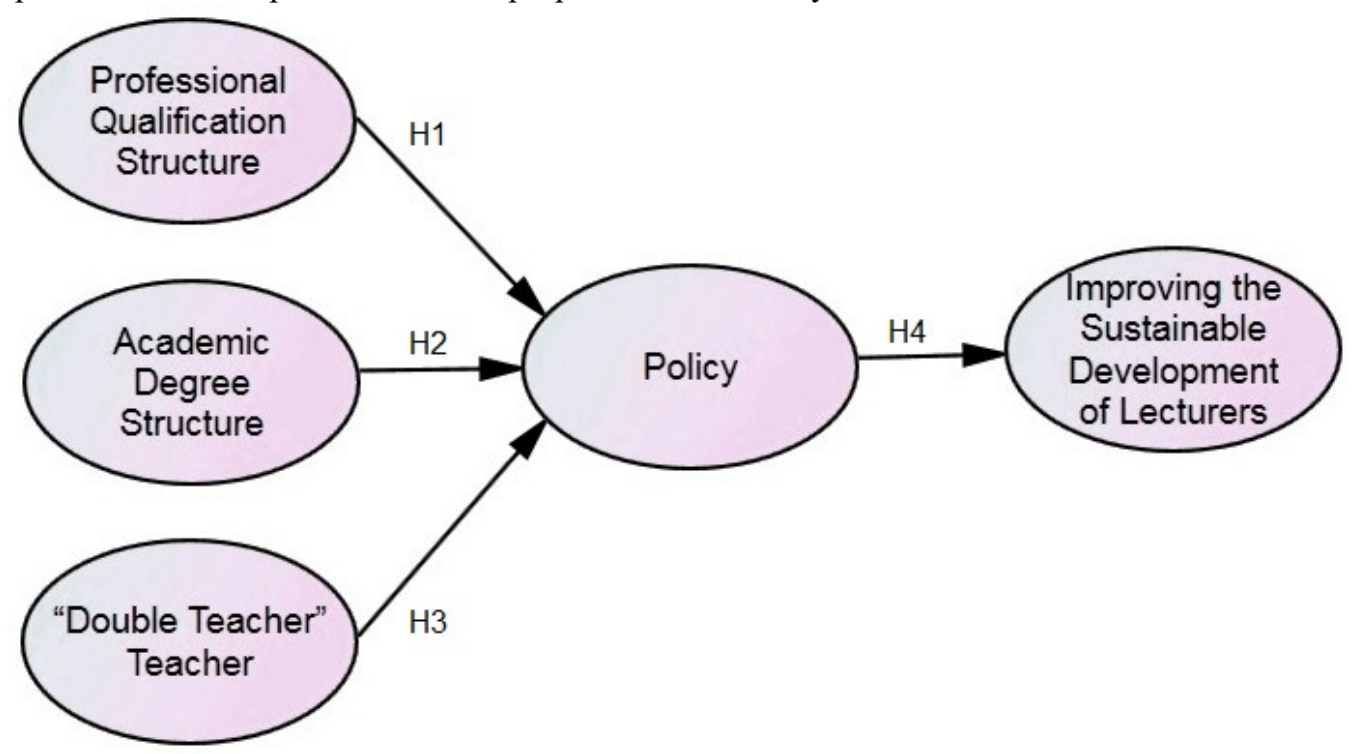

Figure 1: Conceptual Framework

In light of the above and the previous empirical studies, there are several hypotheses formulated. Henceforth, considering the findings of the previous studies, the following hypotheses are established for this study.

Hypothesis 1 (H1): Professional Qualification Structure has a significant positive effect on Policy in Tongren University, Guizhou, China.

Hypothesis 2 (H2): Academic Degree Structure has a significant positive effect on Policy in Tongren University, Guizhou, China.

Hypothesis 3 (H3): "Double Teacher" Teacher has a significant positive effect on Policy in Tongren University, Guizhou, China.

Hypothesis 4 (H4): Policy has a significant positive effect on Improving the Sustainable Development of Lecturers in Tongren University, Guizhou, China.

\section{Research Methodology}

The study at hand has been developed following a quantitative research method and tries to attain further understanding. Data were collected following a random sampling method for the reason that, this method enables researchers to collect data that gives an appropriate representation of the entire population (Hair et al., 2009). At the same time, it also provides a way of gathering data by ensuring randomness as well as preventing the researcher's bias (Hair et al., 2009). Henceforth, the required primary data were collected by following a survey strategy by giving out self-administered questionnaires. Full-time teachers engaged in teaching at Tongren University in Guizhou, China were selected as the sampling frame for this study. In 2018, the total number of fulltime teachers in Tongren University in Guizhou was 719. According to (Sekaran and Bougie, 2016), for a population of 700 to 750 , the highest sample size is 254 . Based on the comprehensive guidelines in (Sekaran and Bougie, 2016), the minimum sample size of the subjects in this study was, 254 respondents.

By using SPSS and AMOS software, the deficiencies were found out from the results obtained after the analysis, and the questionnaire was modified. The same consisted of 54 items. Specialised management personnel from Tongren University Personnel Department used manual distribution questionnaires, and teachers were asked to fill in the university personnel office within 20 days. The total number of questionnaires issued was 254 , the total number of replies received was 254, and the total number of correct response was 254 .

This section starts with the respondents' profile. Table 1 provides a detailed picture of gender, age, teaching age, education level, professional qualifications etc. 
Table 1: Introduction to Respondents

\begin{tabular}{|c|c|c|c|c|c|c|c|c|c|c|c|c|c|c|c|c|}
\hline & \multicolumn{4}{|c|}{ Age } & \multicolumn{3}{|c|}{ Teaching Age } & \multicolumn{3}{|c|}{ Education Level } & \multicolumn{4}{|c|}{ Professional Qualifications } & \multirow[b]{2}{*}{$\stackrel{\vec{\pi}}{0}$} \\
\hline & & શે & î̀ & $\begin{array}{l}\stackrel{9}{+} \\
\stackrel{\rho}{f}\end{array}$ & $\begin{array}{l}\stackrel{n}{n} \\
\text { in } \\
\text { in }\end{array}$ & $\stackrel{n}{n}$ & $\frac{0}{b}$ & $\stackrel{n}{ \pm}$ & 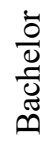 & 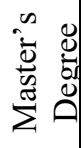 & 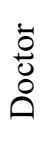 & 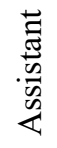 & 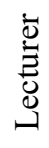 & 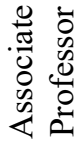 & $\begin{array}{l}\dot{0} \\
\dot{D} \\
\dot{d} \\
\stackrel{0}{0} \\
0\end{array}$ & \\
\hline \multirow{2}{*}{$\frac{\dot{0}}{\stackrel{0}{0}}$} & $\frac{0}{\Sigma^{\pi}}$ & $\nabla$ & fo & $\stackrel{\vartheta}{q}$ & T & $\simeq$ & 2 & $\stackrel{0}{\Xi}$ & $\stackrel{6}{1}$ & 으 & $n$ & 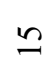 & サ & $\stackrel{\infty}{\infty}$ & 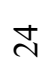 & $\vec{\Xi}$ \\
\hline & $\begin{array}{l}\frac{0}{\pi} \\
\tilde{J} \\
0 \\
\end{array}$ & $r$ & gे & $\stackrel{+}{m}$ & $\hat{\imath}$ & 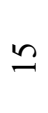 & ำ & $\stackrel{\infty}{\sim}$ & $\hat{6}$ & $\exists$ & $n$ & 2 & กิ & テ & $\cong$ & $\stackrel{m}{\equiv}$ \\
\hline \multicolumn{2}{|c|}{ 全 } & 二 & 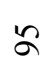 & $\infty$ & 6 & $\widehat{\sim}$ & ले & $\begin{array}{l}\infty \\
\infty\end{array}$ & $\stackrel{\mathscr{\vartheta}}{ \pm}$ & $\bar{a}$ & 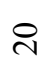 & m & 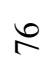 & $\stackrel{n}{\varrho}$ & ले & $\stackrel{+}{2}$ \\
\hline \multicolumn{2}{|c|}{ 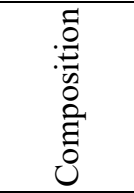 } & $\stackrel{\circ}{\stackrel{\gamma}{+}}$ & $\underset{m}{\stackrel{+}{+}}$ & $\stackrel{2}{\stackrel{2}{2}}$ & $\begin{array}{l}\stackrel{0}{0} \\
\text { ì }\end{array}$ & $\begin{array}{l}\stackrel{0}{0} \\
\stackrel{0}{0}\end{array}$ & $\begin{array}{l}\stackrel{\circ}{\circ} \\
\stackrel{1}{2}\end{array}$ & $\begin{array}{l}\stackrel{0}{0} \\
\stackrel{+}{\pi}\end{array}$ & 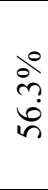 & $\begin{array}{l}\stackrel{0}{ } \\
\infty \\
\ddot{n} \\
m\end{array}$ & $\stackrel{\circ}{\circ}$ & ìn & ڤे & $\frac{\stackrel{\circ}{n}}{\stackrel{\nabla}{\sigma}}$ & $\begin{array}{l}\stackrel{0}{0} \\
\stackrel{n}{n}\end{array}$ & \\
\hline
\end{tabular}

According to the respondents' responses to the items in the questionnaire, Table 2 provides the average scores of five aspects: professional qualification structure, academic degree structure, "double- teacher" teachers, policy optimisation, and sustainable development of the lecturer team. .The scores in the interval [0-4), [4-4.5], and [4.55 ] indicate that the degree of recognition has low, medium, and high levels, respectively. The status quo of the construction of the lecturer team is reflected in three aspects: professional qualification structure, academic degree structure, and "double-skilled" teachers.

Table 2: Levels of The Indicators of The Lecturer Team

\begin{tabular}{l|c|c|c}
\hline & Mean & Standard deviation & Level \\
\hline $\begin{array}{l}\text { Professional Qualification } \\
\text { Structure }\end{array}$ & 4.529982 & 0.2626387 & High \\
\hline Academic Degree Structure & 4.498926 & 0.2566621 & Medium \\
\hline "Double Teacher" Teacher & 4.586614 & 0.2609464 & High \\
\hline Policy & 4.688976 & 0.1372236 & High \\
\hline $\begin{array}{l}\text { Improving the Sustainable } \\
\text { Development of Lecturers }\end{array}$ & 4.550306 & 0.4713314 &
\end{tabular}

The higher the score, the more restrictive conditions exist for the construction of the lecturer team. Table 3 exhibits the surveyed status of the lecturer team, the policy optimisation, and the average score of the sustainable development of the lecturer team with different professional qualifications and different levels of education.

Table 3: Average Scores of Respondents With Different Professional Qualifications and Different Levels of Education

\begin{tabular}{|c|c|c|c|c|}
\hline & $\mathrm{N}$ & $\begin{array}{c}\text { Current Situation of } \\
\text { Lecturer Team }\end{array}$ & \begin{tabular}{|c|} 
Poli \\
cy
\end{tabular} & $\begin{array}{c}\text { Improving The Sustainable Development } \\
\text { of Lecturers }\end{array}$ \\
\hline Assistant Teacher & 34 & 4.78 & 4.92 & 4.72 \\
\hline Lecturer & 76 & 4.61 & 4.74 & 4.60 \\
\hline $\begin{array}{l}\text { Deputy Senior Professional } \\
\text { Qualification }\end{array}$ & $\begin{array}{c}10 \\
5\end{array}$ & 4.40 & 4.58 & 4.45 \\
\hline $\begin{array}{l}\text { Positive Professional } \\
\text { Qualification }\end{array}$ & 39 & 4.55 & 4.67 & 4.57 \\
\hline Bachelor & $\begin{array}{c}14 \\
3 \\
\end{array}$ & 4.59 & 4.74 & 4.59 \\
\hline Master's Degree & 91 & 4.45 & 4.60 & 4.48 \\
\hline Doctor & 20 & 4.58 & 4.74 & 4.61 \\
\hline
\end{tabular}

Besides that, Hair et al. (2009) have mentioned that it is essential to conduct factor analysis, as it helps researchers in summarising the information gathered from a particular set of data. However, before proceeding with EFA, two tests, namely, Kaiser-Meyer-Olkin (KMO) and Bartlett's Test of Sphericity, should be verified for checking the factorability of data (Pallant, 2007). Tabachnick et al. (2001) have indicated that the value of the first 
test (KMO) ranges from 0 to 1 , and for an appropriate analysis it is essential to have at least a value of 0.6 , and for the latter (Bartlett's Test of Sphericity) it is essential to attain a significant $p$-value $(p<.05)$. After running both of these several tests through SPSS, it was observed that the results of both fell within the acceptable range, indicating that the researcher can run EFA. The outcomes of the tests are shown below in Table 4. From EFA, certain items have been derived, and all the items are considered to be significant as they managed to load with a value higher than 0.50 , and any loading above this value is considered to be practically significant by Hair et al. (2009). It shows that the total variance accounted for approximately $72.824 \%$ per cent which is highly adequate. A higher variance is explained when eight components are retained. Cronbach's alpha has also been calculated for all the items of the four variables. It can be seen in Table 4, all items under each of the variables are reliable as they all have surpassed the minimum value of .60 suggested by Hair, Black, Babin, and Anderson (2010).

Table 4: Kaiser-Meyer-Olkin (KMO) \& Bartlett's test

\begin{tabular}{lcc}
\hline Kaiser-Meyer-Olkin Measure of Sampling Adequacy. & .769 \\
\hline & Approx. Chi-Square & 5431.760 \\
Bartlett's Test of Sphericity & Df & .000 \\
\hline
\end{tabular}

Table 5: Result of Exploratory Factor Analysis (EFA)

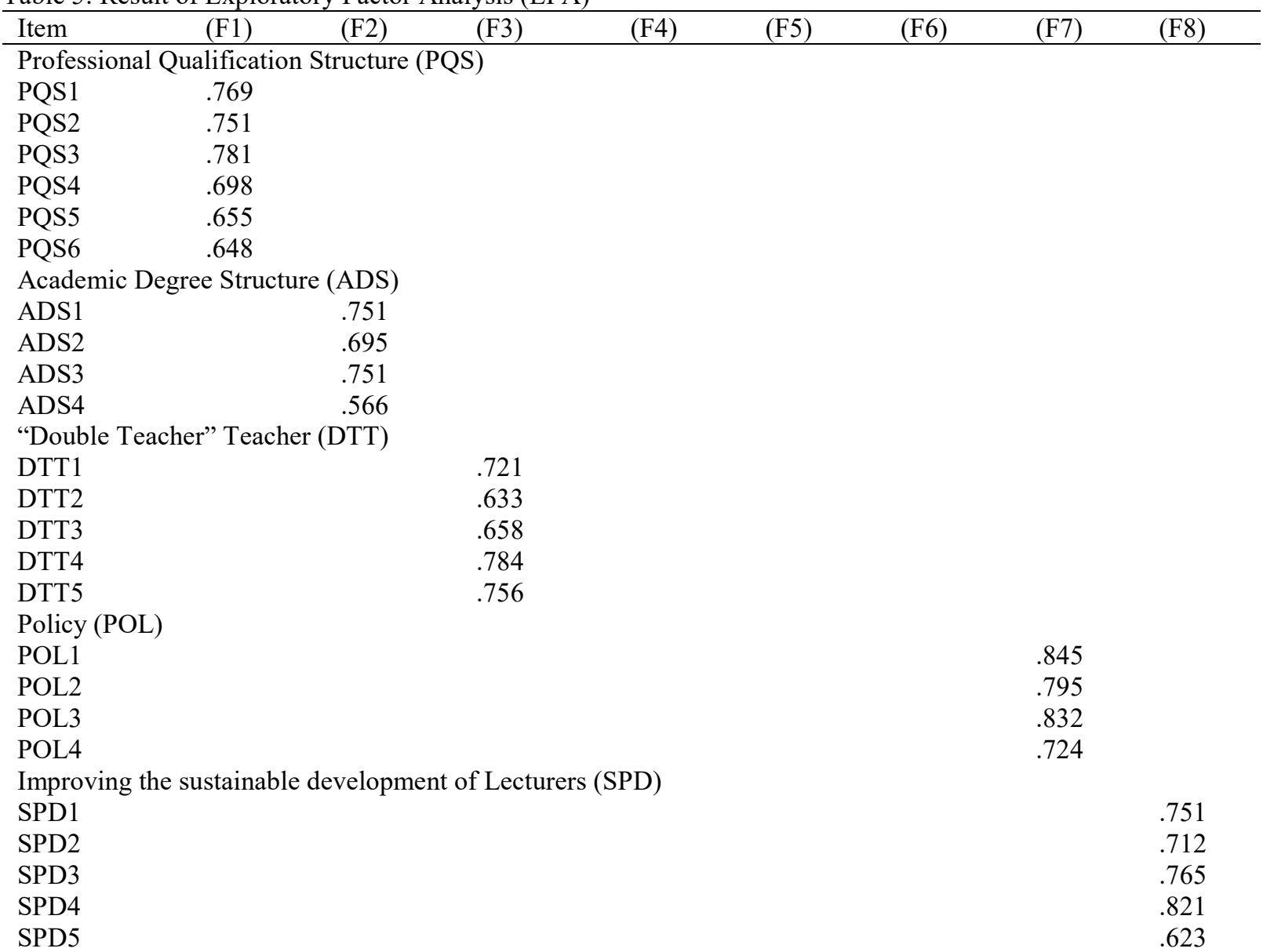

The result of the model revealed that the model is acceptable as it attained the required values for each of the indices as follows: root means square error approximation $($ RMSEA $)=.075$, comparative fit index $(\mathrm{CFI})=.982$, Normed $\chi 2=2.850$ (See Figure 2). 


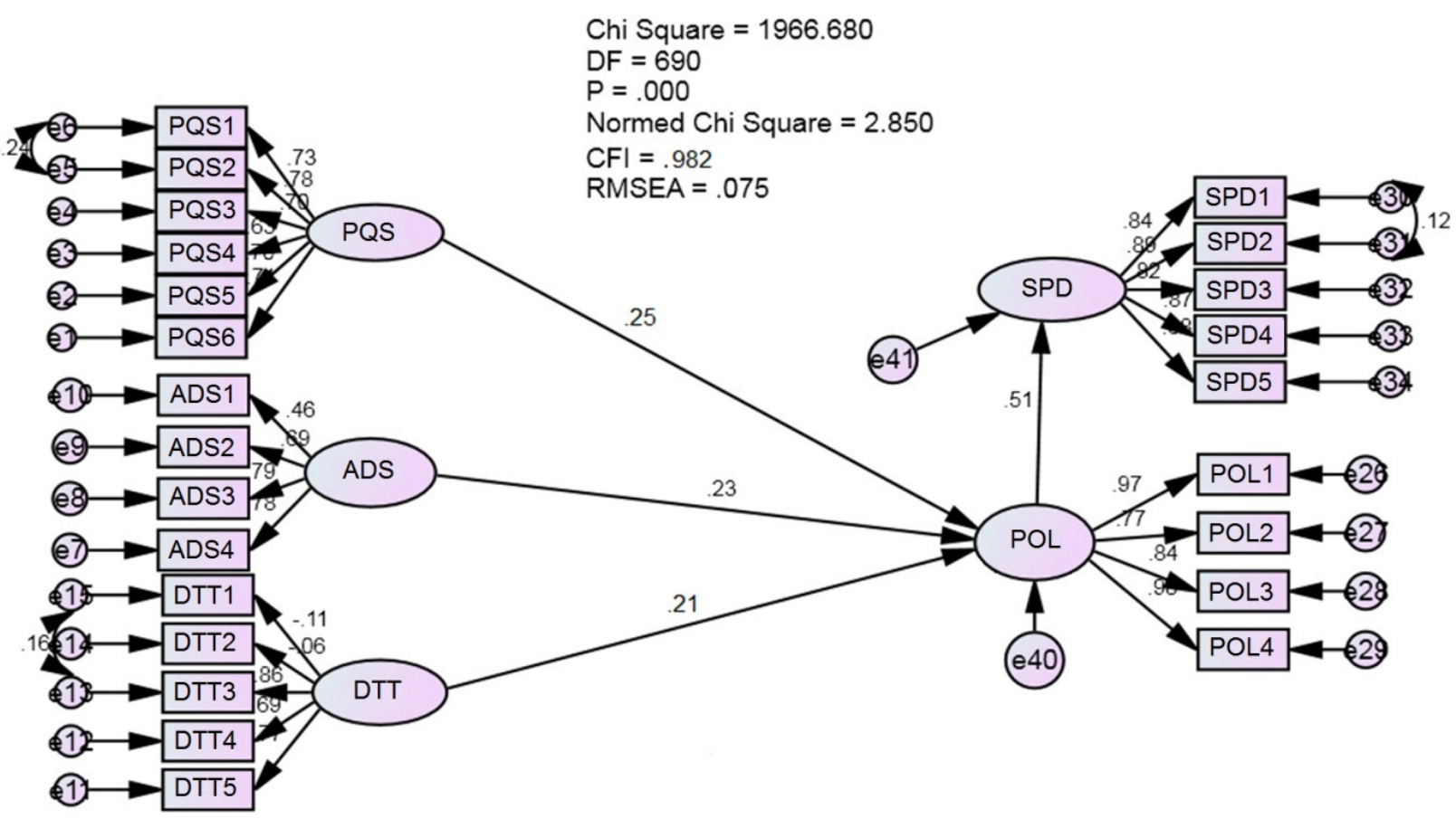

Figure 2: Full-Fledged Conceptual Model

Table 6: Fitness Assessment of the Structural Model.

\begin{tabular}{cccc}
\hline Name of category & Required value & Obtained Value & Comments \\
\hline Absolute fit & RMSEA $\leq 0.08$ & 0.075 & The required value is attained \\
Incremental fit & CFI $\geq 0.90$ & 0.982 & The required value is attained \\
Parsimonious fit & $\chi 2 / \mathrm{df} \leq 3$ & 2.850 & The required value is attained \\
\hline
\end{tabular}

Source: Byrne (2010); Hair, Black, Babin, and Anderson (2010); Kline (2011); Zainudin (2012)

Note. RMSEA = root mean square error approximation; GFI = goodness-of-fit index; CFI = comparative fit index.

Besides the baseline model, the study needs to consider the overall measurement model to test the validity of the analysis. To confirm the construct validity of the study, it requires assessing convergent, discriminant, and facing validity. Most of the factor loadings for each construct (more than .70), average variance extracted (AVE; more than .50), and construct "Double Teacher" Teacher (DTT) (more than .50) show the presence of convergent validity, while discriminant validity is confirmed with the positive difference between AVE and squared correlation ( $\mathrm{r} 2$ ) of the constructs. Here, in all cases, AVE is bigger than squared multiple correlation values and gives the evidence of uniqueness for each construct. Besides, technical support of the literature proves the face validity of the constructs (Table 7).

Table 7: Validity Testing

\begin{tabular}{|c|c|c|c|c|c|c|}
\hline \multicolumn{3}{|l|}{ Construct } & Cronbach's $\alpha$ & \multicolumn{2}{|c|}{$\mathrm{CR}$} & AVE \\
\hline \multicolumn{2}{|l|}{ Professional Qualification Structure (PQS) } & \multicolumn{2}{|c|}{.837} & \multicolumn{2}{|c|}{5.997} & 0.478 \\
\hline \multicolumn{2}{|l|}{ Academic Degree Structure (ADS) } & \multicolumn{2}{|c|}{.779} & \multicolumn{2}{|c|}{4.345} & 0.445 \\
\hline \multicolumn{2}{|l|}{ "Double Teacher" Teacher (DTT) } & \multicolumn{2}{|c|}{.883} & \multicolumn{2}{|c|}{5.765} & 0.554 \\
\hline \multirow{2}{*}{\multicolumn{2}{|c|}{$\begin{array}{l}\text { Policy (POL) } \\
\text { Improving the Sustainable Development of Lecturers (SPD) }\end{array}$}} & \multicolumn{2}{|c|}{.887} & \multicolumn{2}{|c|}{4.215} & 0.813 \\
\hline & & .81 & & & .124 & 0.741 \\
\hline \multicolumn{7}{|l|}{ Table 8: Hypothesis Testing } \\
\hline \multicolumn{3}{|l|}{ Structural path } & Estimate & SE & $\mathrm{CR}$ & $\mathrm{P}$ \\
\hline Policy (POL) & $\leftarrow \begin{array}{l}\text { Professional } \\
\text { Structure (PQS) }\end{array}$ & alification & .476 & .073 & 6.520 & *** \\
\hline Policy (POL) & $\leftarrow \begin{array}{l}\text { Academic Degree } \\
(\mathrm{ADS})\end{array}$ & Structure & .218 & .090 & 2.423 & .016 \\
\hline Policy (POL) & $\leftarrow \begin{array}{l}\text { "Double Teacher" } \\
\text { (DTT) }\end{array}$ & Teacher & .296 & .114 & 2.597 & .002 \\
\hline $\begin{array}{l}\text { Improving the } \quad \text { Sustainable } \\
\text { Development of Lecturers (SPD) }\end{array}$ & $\leftarrow$ Policy $(\mathrm{POL})$ & & .408 & .298 & 1.369 & .017 \\
\hline
\end{tabular}


Table 9: Result of Hypothesis Testing

\begin{tabular}{lll}
\hline Hx & Statement & Decision \\
\hline H1 & $\begin{array}{l}\text { Professional Qualification Structure has a significant positive effect on Policy in Tongren } \\
\text { H2 }\end{array}$ & Accepted \\
H3 & "Doubersity & Accepted \\
H4 & $\begin{array}{l}\text { The policy hee Structure has a significant positive effect on Policy in Tongren University has a significant positive effect on Policy in Tongren University } \\
\text { Lecturers in Tongren University }\end{array}$ & $\begin{array}{l}\text { Accepted } \\
\text { Accepted on Improving the Sustainable Development of }\end{array}$ \\
& Accepted \\
\hline
\end{tabular}

The structural equation model was examined to test the relationship among the constructs. Figure 2 depicts the full model of the four paths hypothesised in the model; all the paths were significant at $\mathrm{p}<0.05$. Therefore, H1, H2, $\mathrm{H} 3$ and $\mathrm{H} 4$ are accepted at 0.5 level of significance $\mathrm{p}>0.000$. The study showed that the Policy (POL) has a positive impact on Improving the Sustainable Development of Lecturers (SPD).

\section{Discussion And Conclusion}

The status quo of the construction of the lecturer team is reflected in three aspects: professional qualification structure, academic degree structure, and "double-skilled" teachers. The professional qualification structure, "double- teacher" teachers, policy optimisation, and lecturer team have high scores for sustainable development. The level of structural scores, the higher the score indicates that there are more restrictive conditions for the construction of the instructor team.

The results of the study are given to the status quo of the construction of the lecturer team, the optimisation of the policy, and the average score of the sustainable development of the lecturer team with different professional qualifications and different levels of education.

In order to discuss whether there is a significant difference in the evaluation of the status quo of the lecturer team by different professional qualifications, the Kruskal-Wallis test is used to obtain a p-value equal to $0.004<0.05$, indicating that the evaluation of the current status of the lecturer team by different professional qualifications exists. Significant differences; whether there is a significant difference in the evaluation of the current status of the lecturer team by different surveyees, the Kruskal-Wallis test shows that the p-value is equal to $0.127>0.05$, indicating that the evaluation of the current situation of the lecturer team does not exist in different academic qualifications.

In order to discuss whether there are significant differences in the evaluation of policy optimisation between different professional qualifications, the Kruskal-Wallis test shows that the p-value is equal to $0.002<0.05$, indicating that the evaluation of policy optimisation by different professional qualifications is significant. Differences: Whether there is a significant difference in the evaluation of policy optimisation among respondents with different academic qualifications, the Kruskal-Wallis test shows that the p-value is equal to $0.041<0.05$, indicating that there are significant differences in the evaluation of policy optimisation among respondents with different academic qualifications.

Whether there is a significant difference in the evaluation of the sustainable development of the lecturer team by different professional qualifications, using the Kruskal-Wallis test, the p-value is equal to $0.006<0.05$, indicating that the different professional qualifications are sustainable for the lecturer team. There is a significant difference in the evaluation; whether there is a significant difference in the evaluation of the sustainable development of the lecturer team by different academic qualifications, the Kruskal-Wallis test shows that the pvalue is equal to $0.099>0.05$, indicating that the lecturer team can use the different academic qualifications. There are no significant differences in the evaluation of sustainable development.

The results of the study, the professional qualification structure, academic degree structure, "double- teacher" teachers, policy optimisation, and the sustainable development of the lecturer team showed a positive linear correlation with a significant correlation.

By referring to the relationship between the professional qualification structure, academic degree structure, "double- teacher" teachers and policy optimisation, and the sustainable development of the lecturer team revealed in the current research, and it can be concluded that it is necessary to upgrade the provincial-level new provinciallevel universities. The level of talent team construction requires not only the policy optimisation at the university level but also the government to provide policy protection in many aspects.

Improve relevant laws, regulations and policies. The traditional working methods of the government use administrative instructions and policies to guide the development and construction of colleges and universities. The coherence and stability of this method have significant problems. Administrative management often changes significantly because of the change of leaders. Not conducive to long-term sustainable development. Under the new situation, this traditional way is challenging to adapt to the development of colleges and universities, and the government needs to turn more to use relevant laws, regulations and policies to guide the development of colleges and universities. Provincial universities must continuously improve the development of high-level talent lecturers. It requires the government to provide more service spirit and pay attention to policy guidance. For example, 
qualifications, selection methods, training and training methods for higher education lecturers must be established relevant laws, regulations and policies to ensure that provincial colleges and universities can effectively improve the quality and quantity of high-level talent lecturers. Otherwise, it will be challenging to establish a genuinely applied university.

Increase the policy of capital investment in provincial universities. On the one hand, it is necessary to give provincial colleges and universities sufficient financial support to improve the teaching conditions of high-level personnel teaching and scientific research and to introduce and train senior professional qualification talents and highly educated degree talents. On the other hand, it is necessary to improve the high-level talents treatment policy, give high-level talents of universities high enough economic treatment and social status, reduce the loss of highlevel talents, and ensure that they put all their energy into teaching and research, thus promoting the entire social economy.

Establish a policy of decentralisation of power in colleges and universities. The government's management model and the university's management model can be said to be completely different. If the university is managed according to the government's management model, it is impossible to establish a modern university. Colleges and universities must achieve self-use within the total number of approved preparations, position self-determination, high-level professional titles account for a higher proportion of job placement, self-determination of employment conditions, and independent employment of high-level talents. Only in this way can we successfully upgrade highlevel talent lecturers team development.

Given the current situation of the construction of high-level secondary talent lecturers in provincial universities, taking the problems existing in the construction of high-level talent lecturers in Tongren University as an example, the improvement of the construction of high-level talent lecturers in provincial universities can be started from the following aspects:

Reform the professional qualification review system. With the continuous development of provincial-level universities, the limitations and lags of the original professional qualification review system have become more and more visible, and have even become a bottleneck restricting the development of high-level talents in colleges and universities. In order to meet the needs of cultivating high-level talents, provincial-level colleges and universities need to formulate scientific standards suitable for university development in the process of professional qualification assessment. It is not only the only criterion for judging teaching and scientific research workload, but also professional practice application skills. Only factors that must be considered can only effectively promote the sustainable development of high-level talents in colleges and universities.

Improve the policy of upgrading academic degrees. Deepen the reform of the university's high-level talent team construction and development model, improve the high-level talent introduction mechanism, high-level personnel training mechanism and management mechanism, etc., and encourage lecturers to improve their academic degree. For retired teachers with high academic qualifications and senior professional qualifications, the university should implement a re-employment system, encourage policies for high-level talents who are willing to continue to re-employ, and effectively use high-level talents in universities to promote the sustainable development of provincial universities.

Establish and improve the "double- teacher" teacher system. Reform the appointment system and evaluation methods for teachers, actively introduce or hire an outstanding professional and technical talents, management talents and highly skilled personnel of industry-recognised enterprises as professional construction leaders, serve as full-time and part-time teachers, and systematically send teachers to enterprises for training and job postings practice exercise. Through the systematic evaluation of teaching evaluation, performance appraisal, job qualification (professional qualification), salary incentives, university-enterprise exchanges, etc., the teachers' initiative and enthusiasm for improving their practical ability are enhanced, and the sustainable development of the quality of the entire high-level talent lecturer team is promoted.

\section{References}

Pan Yiyuan, \& Shi Huixia. (2009). A Historical Exploration of the Cultivation of Applied Talents. Jiangsu Higher Education, 1(7).

Pan Yiyuan, \& Che Rushan. (2009). A Brief Discussion on the Orientation of Applied Undergraduate Colleges. Higher Education Research, 5, 35-38.

Zhu Shizhong. (2010). On the transformation and development of the teaching staff of applied undergraduate colleges. Contemporary Educational Science, 9, 47-49.

Yan Haiyan, \& Wu Changfa. (2011). Study on the Difficulties and Countermeasures of the Construction of Young Teachers in Newly-built Undergraduate Colleges. Journal of National Academy of Education Administration, 201(1), 5 .

Huang Jianxiong, \& Zhang Jiping. (2013). Problems and Countermeasures of the Structure of University Teachers in China. Continued Education Research, 1.

Chen Xiaohu, \& Yang Xiang. (2013). 14 basic problems in the development of new applied undergraduate colleges. 
Chinese University Teaching, 1(17), r22.

Zhou Weidong. (2013). Exploration of the construction of "double-skilled" teachers in newly-built applied undergraduate colleges. Educational Exploration, 3, 83-84.

Wang Xiaogang, \& Feng Wei. (2013). Problems and Countermeasures in the Construction of Double-Teacher Teams in Higher Vocational Colleges. Educational Exploration, 5, 96-97.

Zhang Yong. (2014). Retrospection, reflection and prospect of the construction of teaching staff in applied undergraduate colleges. Heilongjiang Higher Education Research, 2, 75-78.

Zhang Xiaoxu. (2014). Research on the construction and optimization of local college teachers. Journal of National Academy of Education Administration, 4, 38-42.

Zhang Weiping. (2014). Analysis of the construction path of "double-skilled" teachers in higher vocational colleges from the perspective of collaborative innovation. Higher Education Research, 4, 56-59.

Zhang Yingqiang, \& Jiang Hualin. (2014). Reflections on Some Issues Concerning the Transformation and Development of Local Undergraduate Universities. Modern University Education, 6(1), 8.

Dong Liping. (2014). Transformation and development of local universities and the application of applied technology universities. Educational Research, 35(8), 67-74.

Zhang Xiuwu, \& Xu Qingyu. (2014). Reflections on the transformation and development of local undergraduate colleges. China Higher Education Research, 10, 93-97.

Chen Yongbin. (2014). The Dilemma and Strategy of Transformation and Development of Local Undergraduate Colleges. China Higher Education Research, 11, 38-42.

Chen Feng. (2014). Reflections on some issues concerning the transformation and development of some ordinary undergraduate universities. China Higher Education, 12.

Qu Dianbin, \& Zhao Yushi. (2014). Problems and Countermeasures in the Transformation and Development of Local Undergraduate Universities. China Higher Education, 12, 25-28.

Chen Jianguo. (2014). Wisconsin Thought and the Transformation of Local Universities in China[j]. Higher Education Research, 12, 46-53.

Yan Xinping, \& Chen Xianming. (2014). Deepening the reform and taking the road of the development of applied technology universities. China Higher Education, 2.

Li Mingqiang, \& Wu Wenwen. (2015). Enlightenment of the experience of foreign applied technology universities on the transformation of local universities in China. Higher Education Review, 1, 170-184.

Zhou Aizhen. (2015). The transformation of local undergraduate colleges and universities needs to strengthen the research of colleges and universities. Higher Engineering Education Research, (3), 023-023.

Jia Wensheng, \& Liang Ningsen. (2015). The construction of a "double- teacher" teacher team in higher vocational colleges based on the school-enterprise community. China Higher Education Research, 1, 92-95.

Chen Xiao. (2015). Breaking through the discipline: a new perspective for the transformation and development of higher education institutions--consideration of the application-oriented talent training system with reconstruction ability. Chinese University Teaching, 2, 21-25.

Yang Yongfei, \& Zhao Xiaoyu. (2015). Promoting the Construction of Applied Technology University to Serve the Local Economic and Social Development--Some Thoughts on the Transformation and Development of Local Universities[j]. Chinese Adult Education, (3), 19-22.

Hou Changlin, Luo Jing, \& Ye Dan. (2015). The choice of new undergraduate colleges in the field of applied universities[j]. Educational Research, (4): 61-69

Guo Qiang, \& Zhou Tong. (2015). Sino-foreign cooperative education: an effective path for the transformation and development of local undergraduate colleges. Education Review, (4), 9-11.

Yuan Wei. (2015). Governance Structure in the Transformation of Local Universities to Applied Technology Universities 1. Modern Education Management, (6), 12-15.

Liu Yanjun. (2015). Research on the Transformation Development Model of Local Undergraduate Universities [j]. China Higher Education Research, 10, 82-86.

$\mathrm{Cao} \mathrm{Yu}$. (2015). The transformation and development of local undergraduate colleges is a response to the situation [j]. Journal of Hebei Normal University: Educational Science Edition, 17(1), 62-66.

Ying Xiong. (2015). "Two-way and pluralistic" teacher construction, the key to the transformation and development of local undergraduate universities [j]. Educational Development Research, (19), 40-46.

Zhou Shaosen, \& Zhang Yang. (2015). Adapting to the new normal and vigorously promoting the transformation and development of local universities. China Higher Education, (19), 28-29.

Li Chaoyou, Qiao Pengchao, Liu Chaoyang, \& Fu Yuan. (2016). Research on the optimization of the structure of full-time teachers in China's universities. Coal Higher Education, 34(4), 103-107.

Zhong Binglin, \& Wang Xinfeng. (2016). Analysis of Some Hot Issues in the Transformation of Local General Undergraduate Colleges in China. Educational Research, 37(4), 4-11.

Li Yan, Xue Haiqin, \& Chen Jiangbo. (2016). Problems in the construction of "double-skilled" teachers in applied undergraduate colleges and countermeasures. Western Quality Education, 2(5), 24-24. 
Yao Xu. (2016). Research on the construction of faculty in new undergraduate colleges under the background of transformation. Education Exploration, (5), 80-82.

Li Jieming. (2017). Research on the countermeasures for the construction of "double-skilled" teachers in newlybuilt undergraduate colleges under the background of economic transformation. Economic Research Guide, (27), 136-137.

First A. Author (Yang Zhongfei), He is PhD scholar,Management and Science University, Malaysia ,He born in Tongren City, Guizhou Province, China in December 1969, Dean of Continuing Education, Tongren University, mainly engaged in human resources management research.

Second A. Author (Dr Foong Chee Haur), He has earned a PhD Degree from Management and Science University Malaysia (MSU). His Doctoral research was related to marketing, advertising practice and Malaysian online business. Also, he has published numerous articles in international refereed journals in the area of marketing, online businesses and management etc. Moreover, he has several years of teaching experience in various subjects related to marketing, international business, management, organisational behaviour. He also has extensive experience with the corporate environment and consulting practice.

Third A. Author (Dr S.M. Ferdous Azam ), He has earned a PhD Degree from International Islamic University Malaysia (IIUM), who is currently working in Management and Science University (MSU) Malaysia. His Doctoral research was related to financial economics, management practice and Malaysian small and medium enterprises (SMEs). Also, he has presented his research works in many international conferences, as well as published numerous articles in international refereed journals in the area of finance, economics, marketing, businesses and management, small and medium enterprises, e-commerce, education etc. Moreover, he has several years of teaching experience in various subjects related to the finance, economics, management and research methodology in three different universities. 